\title{
THE
}

\section{Antimicrobial Peptides for Use in Oyster Aquaculture: Effect on Pathogens, Commensals, and Eukaryotic Expression Systems}

\author{
Tarquin Dorrington \\ University of Rhode Island \\ Marta Gomez-Chiarri \\ University of Rhode Island, gomezchi@uri.edu
}

Follow this and additional works at: https://digitalcommons.uri.edu/favs_facpubs

Terms of Use

All rights reserved under copyright.

\section{Citation/Publisher Attribution}

Dorrington, T., \& Gomez-Chiarri, M. (2008). Antimicrobial Peptides for Use in Oyster Aquaculture: Effect on Pathogens, Commensals, and Eukaryotic Expression Systems. Journal of Shellfish Research, 27(2), 365-375. doi: 10.2983/0730-8000(2008)27[365:APFUIO]2.0.CO;2

Available at: http://dx.doi.org/10.2983/0730-8000(2008)27[365:APFUIO]2.0.C0;2

This Article is brought to you for free and open access by the Fisheries, Animal and Veterinary Sciences at DigitalCommons@URI. It has been accepted for inclusion in Fisheries, Animal and Veterinary Sciences Faculty Publications by an authorized administrator of DigitalCommons@URI. For more information, please contact digitalcommons-group@uri.edu. 


\section{Antimicrobial Peptides for Use in Oyster Aquaculture: Effect on Pathogens, Commensals, and Eukaryotic Expression Systems}

Author(s): Tarquin Dorrington and Marta Gomez-Chiarri

Source: Journal of Shellfish Research, 27(2):365-373. 2008.

Published By: National Shellfisheries Association

DOI: http://dx.doi.org/10.2983/0730-8000(2008)27[365:APFUIO]2.0.CO;2

URL: http://www.bioone.org/doi/full/10.2983/0730-8000\%282008\%2927\%5B365\%3AAPFUIO

$\% 5 \mathrm{D} 2.0 . \mathrm{CO} \% 3 \mathrm{~B} 2$

BioOne (www.bioone.org) is a nonprofit, online aggregation of core research in the biological, ecological, and environmental sciences. BioOne provides a sustainable online platform for over 170 journals and books published by nonprofit societies, associations, museums, institutions, and presses.

Your use of this PDF, the BioOne Web site, and all posted and associated content indicates your acceptance of BioOne's Terms of Use, available at www.bioone.org/page/terms of use.

Usage of BioOne content is strictly limited to personal, educational, and non-commercial use. Commercial inquiries or rights and permissions requests should be directed to the individual publisher as copyright holder. 


\title{
ANTIMICROBIAL PEPTIDES FOR USE IN OYSTER AQUACULTURE: EFFECT ON PATHOGENS, COMMENSALS, AND EUKARYOTIC EXPRESSION SYSTEMS
}

\author{
TARQUIN DORRINGTON ${ }^{\mathbf{1}}$ AND MARTA GOMEZ-CHIARRI ${ }^{2 *}$ \\ ${ }^{1}$ Graduate School of Oceanography, University of Rhode Island, Narragansett, Rhode Island 02882; \\ ${ }^{2}$ Department of Fisheries, Animal and Veterinary Science, University of Rhode Island, 23 Woodward \\ Hall, Kingston, Rhode Island 02881
}

\begin{abstract}
Two antimicrobial peptides (AMPs) of marine origin, tachyplesin from the Japanese horseshoe crab, Tachypleus tridentatus, and pleurocidin-amide from the winter flounder, Pseudopleuronectes americanus, were tested for their potential effectiveness in disease treatment in oyster aquaculture. Tachyplesin had a greater antimicrobial effect than pleurocidin-amide against a range of gram-positive and gram-negative bacteria, with minimum inhibitor concentrations in the range of 0.625 to $5 \mu \mathrm{g}$ $\mathrm{mL}^{-1}$. Tachyplesin $\left(50 \mu \mathrm{g} \mathrm{mL} L^{-1}\right)$ was also more effective than pleurocidin-amide $\left(250 \mu \mathrm{g} \mathrm{mL}^{-1}\right)$ against the oyster protozoan parasite Perkinsus marinus, reducing its viability to $9 \%$ versus $22 \%$ in vitro. Both peptides were unaffected by variations in $\mathrm{pH}$ and salinity that would be encountered in marine culture conditions. Candidate algal and yeast for expression and feed-based delivery of recombinant AMPs were largely unaffected by tachyplesin and pleurocidin at concentrations that inhibited bacterial growth but were sensitive to concentrations that reduced the viability of $P$. marinus. Several proteases, including those of oyster and parasitic origin, decreased AMP activity, but tachyplesin was affected to a much lesser degree than pleurocidin-amide. Coincubation of homogenates from oyster digestive tissues with tachyplesin and pleurocidin-amide was found to reduce the abundance of colony forming units in the tissue. Tachyplesin was more effective against gram-negative bacteria present in oyster tissues, whereas pleurocidin-amide was more effective against gram-positive bacteria. Tachyplesin was considered a better candidate than pleurocidin-amide for feed-based delivery applications in oyster aquaculture.
\end{abstract}

KEY WORDS: antimicrobial peptide, disease treatment, oyster, pleurocidin, Perkinsus marinus, tachyplesin

\section{INTRODUCTION}

The expansion of the molluscan bivalve aquaculture industry is constrained by disease causing pathogens, and contamination by human pathogenic bacteria, with corresponding risks to the bivalve and the consumer. The most significant diseases of adult bivalves are caused by protozoan parasites in the phyla Perkinsozoa, Haplosporidia, and Paramyxea (Berthe et al. 2004, Burreson \& Ford 2004, Carnegie \& Cochennec-Laureau 2004, Villalba et al. 2004). Pathogenic bacteria, including several Vibrio species, can cause severe losses in hatcheries (Paillard et al. 2004). Moreover, contamination of raw shellfish with Vibrio vulnificus and $V$. parahemolyticus is a problem for the human consumer, causing illness and possibly fatal gastroenteritis and septicemia, particularly among immunocompromised humans (Gulig et al. 2005, Yeung \& Boor 2004).

Treatment of disease outbreaks in shellfish hatcheries usually involves antibiotic use. However, this practice is highly regulated because of concerns that antibiotic residues are left in consumable meat, and that overuse can lead to the development of resistant bacteria (Chinabut \& Puttinaowarat 2005). Over the past two decades there has been a concerted effort to isolate and characterize antimicrobial peptides (AMPs) as an alternative to antibiotics (Mookherjee \& Hancock 2007, Pereira 2006), as well as for the creation of disease-resistant strains of fish through transgenesis (Buchanan et al. 2001, Morvan et al. 1994, Sarmasik et al. 2002). These peptides are a major component of innate immune systems, and are found in many tissues and cell types in numerous species, including mammals, insects, fish, and amphibians. Their mechanisms of action and structures are varied, but they all kill microorganisms rapidly (Pereira 2006).

*Corresponding author. E-mail: gomezchi@uri.edu
More than 1,000 AMPs of eukaryotic origin have been characterized to date, and the number is rapidly growing (Fjell et al. 2007, Wang \& Wang 2004). A number of these peptides have been isolated from marine organisms, including oysters (Tincu \& Taylor 2004, Gueguen et al. 2005, Seo et al. 2005, Gonzalez et al. 2007). Pleurocidin is found in the mucoussecretory cells of the skin, intestine, and gills of the winter flounder, Pseudopleuronectes americanus Walbaum (Douglas et al. 2003). It is one of the best characterized marine peptides in the $\alpha$-helical class, and has been shown to have a broad activity against gram-positive and gram-negative bacteria (Cole et al. 1997, Cole et al. 2000). The best characterized $\beta$-sheet peptides of marine origin are the tachyplesins. Tachyplesin I is a $17-$ residue peptide from the Japanese horseshoe crab, Tachypleus tridentatus Leach (Nakamura et al. 1988). It is reported to inhibit gram-positive and gram-negative bacteria, and fungi (Miyata et al. 1989). Tachyplesin has also been shown to inactivate a virus (Murakami et al. 1991) and reduce the viability of Perkinsus marinus (Morvan et al. 1997).

Antimicrobial peptides of marine origin could potentially be used for the control of pathogens in aquaculture. Pleurocidin and tachyplesin have no hemolytic or cytotoxic effect on oyster or human cells at concentrations toxic to bacteria (Morvan et al. 1997, Burrowes et al. 2004). Moreover, because of the geneencoded nature of AMPs, they could be produced inexpensively using well-characterized expression systems. If properly developed, these expression systems could not only be constructed to produce antimicrobial peptides but also could be used to direct the peptide to the site of application (most commonly the bivalve gut and gills) using a feed-based delivery strategy. Yeast expression systems have the advantage of being able to express peptides of eukaryotic origin with the correct posttranslational modifications (Ingham \& Moore 2007). In addition, yeast is already used in the aquaculture industry as a probiotic and feed 
for Artemia species (Patra \& Mohamed 2003), as a growth promoter in finfish (Lara-Flores et al. 2003), and as a immunostimulant (Vici et al. 2000). It is our hypothesis that these two characteristics can be combined to produce a yeast strain capable of producing an antimicrobial peptide that could be delivered to shellfish to prevent and treat infectious diseases, or provide a useful system for facilitating research on disease mechanisms. This technology could eventually be applied to the production of peptide-secreting microalgae, more suitable than yeast cells as feeds for shellfish aquaculture.

We investigated the potential of two marine antimicrobial peptides, tachyplesin and pleurocidin, in the development of a system for the feed-based delivery of recombinant peptides for oyster aquaculture. These two peptides were selected because of their differing structures, known low toxicity to bivalve and human cells, and their potency and spectrum of activity in marine environments (Burrowes et al. 2004, Cole et al. 1997, Morvan et al. 1997). We report that the candidate peptides are effective against marine pathogens, yet nontoxic to candidate organisms that could be used to express recombinant proteins, at salinity, $\mathrm{pH}$, and protease conditions likely to be encountered in oyster culture conditions. In addition we determined if oysters feed on candidate organisms used for recombinant expression. The effect of these peptides on the naturally occurring bacterial flora of oysters was also investigated, to determine the potential effect on oyster commensals and symbionts.

\section{MATERIALS AND METHODS}

\section{Oyster Parasites}

A Perkinsus marinus stock culture (Charlestown Pond, RI) (Reece et al. 2001) was obtained from D. Bushek (Haskin Shellfish Research Laboratory, Point Norris, NJ). The parasite was cultured at $28^{\circ} \mathrm{C}$ in sterile Dulbecco's Modified Eagle: Ham's F-12 medium (DME/Ham's F-12) (Sigma) in seawater (Instant Ocean, 10\%o) supplemented with $17.9 \mathrm{mM}$ sodium bicarbonate, $65 \mathrm{mM}$ HEPES, $100 \mathrm{U} \mathrm{mL}^{-1}$ of penicillin, $100 \mu \mathrm{g}$ $\mathrm{mL}^{-1}$ streptomycin, and $2 \%(\mathrm{v} / \mathrm{v})$ fetal bovine serum (Anderson \& Beaven 2001).

\section{Bacterial Strains}

Test bacterial organisms from $-70^{\circ} \mathrm{C}$ frozen stocks were streaked on appropriate agar plates $24 \mathrm{~h}$ prior to the antimicrobial assays. Escherichia coli ZK4 and D31 were grown on Luria Bertani (LB) at $37^{\circ} \mathrm{C}$. Pseudomonas atlantica (ATCC 19,262), Photobacterium damselae damselae (Genbank DQ005203), Vibrio harveyi DN01 (Gauger et al. 2006), V. vulnificus LA624 FDA/GC5L, V. parahemolyticus DAL1094 FDA/GC5L (courtesy of K. LaValley, Spinney Creek Shellfish, ME), and $V$. anguillarum M93Sm (Denkin \& Nelson 1999) were grown on $\mathrm{LB}$ supplemented with $10 \mathrm{~g} \mathrm{~L}^{-1}$ of $\mathrm{NaCl}$ (LB20) plates at $28^{\circ} \mathrm{C}$. A gram-positive Bacillus sp., isolated from the mucus of infected flounder (DQ005191, Gauger et al. 2006), was cultured on sheep's blood agar plates at $19^{\circ} \mathrm{C}$.

\section{Yeast and Micro Algal Candidates for Expression Systems}

The yeasts Saccharomyces cerevisiae (INVSc1, Invitrogen) and Pichia pastoris (X-33 wild type, Invitrogen) were grown on
Yeast Peptone Dextrose agar (YPD) at $28^{\circ} \mathrm{C}$. The microalgae Chlamydomonas reinhardtii and Chlamydomonas pulsatilla (kindly provided by R. Sayre, Ohio State University, Columbus, $\mathrm{OH}$ ) were grown initially on Tris-acetate-phosphate (TAP) agar plates (Tris, TAP salts, phosphate solution, Hunter trace elements, glacial acetic acid, yeast extract) (Gorman \& Levine 1965), then in liquid TAP medium (without yeast extract) at $19^{\circ} \mathrm{C}$. The diatom Skeletonema costatum (kindly provided by G. J. Smith, Moss Landing Laboratory, CA) was cultured on Marine Agar (MA) plates at $19^{\circ} \mathrm{C}$.

\section{Antimicrobial Peptides}

Tachyplesin I (KWC ${ }^{\mathrm{a}} \mathrm{FRVC} \mathrm{C}^{\mathrm{b}} \mathrm{YRGIC}^{\mathrm{b}} \mathrm{YRRC} \mathrm{R}^{\mathrm{a}} \mathrm{R}-\mathrm{NH}_{2}$, where superscript letters define the disulfide-connected cysteine residues) was obtained from Bachem Bioscience. Pleurocidinamide (GWGSFFKKAAHVGKHVGKAALTHYL- $\mathrm{NH}_{2}$ ) was custom synthesized by Mimotopes (http://www.mimotopes. com). Antimicrobial peptides were resuspended in double distilled water $\left(\mathrm{ddH}_{2} \mathrm{O}\right)$ to $10 \mathrm{mg} \mathrm{mL}^{-1}$ and stored at $4^{\circ} \mathrm{C}$. Peptides were checked for correct sequence and structure by mass spectrometry and high performance liquid chromatography.

\section{Antimicrobial Assays}

Antimicrobial assays were carried out following the guidelines of the National Committee for Clinical Laboratory Standards (NCCLS) modified for marine pathogens (Dalsgaard 2001). For assays testing antimicrobial activity against bacterial strains, Cation Supplemented Mueller-Hinton Broth (CSMHB) was prepared by supplementing MHB (Difco) with $\mathrm{Mg}^{2+}$ and $\mathrm{Ca}^{2+}$ to final concentrations of $20 \mathrm{mg} \mathrm{L}^{-1}$ and $10 \mathrm{mg} \mathrm{L}^{-1}$ respectively. For halophilic strains, such as marine vibrios, sterile $5 \mathrm{M}$ sodium chloride $(\mathrm{NaCl})$ solution was added to bring the $\mathrm{NaCl}$ concentration to $1.5 \%$. For those experiments involving the testing of AMPs at various salinities, $\mathrm{NaCl}$ concentration was adjusted to $0 \%, 1.5 \%, 2.0 \%, 2.5 \%$, and $3.0 \%$ (equivalent to $0 \%$ to $30 \%$ seawater salinities). YPD media without supplements was used for those experiments involving $S$. cerevisiae and $P$. pastoris. TAP medium was used for the Chlamydomonas spp. and S. costatum. For testing of the effect of $\mathrm{pH}$ on AMP activity, media were adjusted to one of three different $\mathrm{pH}$ levels $(6.0,7.0$, or 8.0).

Bacteria from stocks were grown overnight on the appropriate solid media and at the indicated temperature. Three to five colonies of each test organism were aseptically taken from culture plates and suspended in $1 \mathrm{~mL}$ of $0.9 \%$ sterile saline by vortexing. Bacterial concentration was determined by measuring optical density (OD) at $650 \mathrm{~nm}$ on a microplate reader (Molecular Devices Spectra MAX 340). Bacterial concentration in colony forming units $(\mathrm{CFU}) \mathrm{mL}^{-1}$ was calculated using previously determined calibration curves showing the relationship between $\mathrm{CFU} \mathrm{mL} \mathrm{mL}^{-1}$ and $\mathrm{OD}_{650}$ for each organism. Bacterial solutions were adjusted to an inoculum concentration of $10^{4} \mathrm{CFU} \mathrm{mL} \mathrm{m}^{-1}$ in various culture media. Microalgae and yeast were counted using a hemocytometer and adjusted to $10^{4}$ cells $\mathrm{mL}^{-1}$ of media.

Antimicrobial peptides were diluted in the appropriate media and 1:2 dilution series of each $(100 \mu \mathrm{l}$ per well) were prepared in duplicate columns in a 96-well plate with U-shape wells (Becton Dickinson), followed by the addition of $100 \mu \mathrm{l}$ of 
the inoculum suspension containing $10^{4} \mathrm{CFU} \mathrm{mL}^{-1}$ of the test organism. Final concentrations of the AMP in the wells ranged from 0.15 to $5 \mu \mathrm{g} \mathrm{mL}^{-1}$ for bacterial strains, from 0.62 to $20 \mu \mathrm{g}$ $\mathrm{mL}^{-1}$ for yeast and most micro algal strains, and from 1.25 to 50 $\mu \mathrm{g} \mathrm{mL} \mathrm{L}^{-1}$ for $S$. costatum. In addition, each plate had a negative control $(100 \mu \mathrm{L}$ of $0.5 \mathrm{M} \mathrm{NaOH}+100 \mu \mathrm{L}$ inoculum), a positive control $(100 \mu \mathrm{L}$ media $+100 \mu \mathrm{L}$ inoculum $)$, and a blank sterility control $(200 \mu \mathrm{L}$ of media). All procedures were carried out in sterile conditions, and plates were incubated in a humidified chamber at the appropriate temperature for growth. Turbidity $\left(\mathrm{OD}_{650}\right)$ was examined at $24 \mathrm{~h}$ after addition of inoculum, using a microplate reader. Minimum inhibitory concentration (MIC) was defined as the lowest concentration for which there was no growth apparent to the unaided eye. For Chlamydomonas spp., readings were carried out after $120 \mathrm{~h}$, because of the slow growing nature of these microalgae.

\section{Effect of Antimicrobial Peptides on Perkinsus marinus Viability}

A tetrazolium-based colorimetric assay was used to determine effects of antimicrobial peptides on $P$. marinus viability (Dungan \& Hamilton 1995). This colorimetric method determines the number of viable cells by measuring levels of the compound 3-(4,5-dimethylthiazol-2-yl)-5(3-carboxymethonyphenol)-2-(4-sulfophenyl)-2H-tetrazolium (MTS) that are reduced by nicotinamide adenine dinucleotide (NADH) in metabolically active cells. Cells from an exponentially growing culture of $P$. marinus were collected by centrifugation at $\times 500 \mathrm{~g}$ for $15 \mathrm{~min}$ at room temperature, resuspended in low-nutrient medium $(0.1 \times$ DME/Ham's F-12 medium w/10\% sterile artificial seawater (SASW), without phenol red), counted using a hemocytometer under the microscope, and diluted to a final concentration of $4 \times 10^{6}$ cells $\mathrm{mL}^{-1}$ in low nutrient medium. Peptide dilution series (1:2) were made in the low nutrient medium and $50 \mu \mathrm{L}$ of each dilution were added to duplicate wells. Fifty microliters of $P$. marinus cells were added to each well and the plate incubated for $3 \mathrm{~h}$ at $28^{\circ} \mathrm{C}$ to allow cell killing to occur. Final concentrations of the peptide in this mix ranged from 0.36 to $50 \mu \mathrm{g} \mathrm{mL}^{-1}$ for tachyplesin and from 3.12 to $200 \mu \mathrm{g}$ $\mathrm{mL}^{-1}$ for pleurocidin-amide. After incubation, $100 \mu \mathrm{L}$ of fullstrength DME/Ham's F-12 medium without phenol red was added, and the plate was incubated for $48 \mathrm{~h}$ at $28^{\circ} \mathrm{C}$ to allow proliferation of cells. Ten microliters of CellTiter 96 AQueous One Solution (Promega) were added to every well, and the plate incubated for $1-4 \mathrm{~h}$ before reading absorbances at $490 \mathrm{~nm}$ on a microplate reader. Viability estimates were calculated based on controls without peptide (media only).

\section{Effect of Proteases on Antimicrobial Peptide} Activity Against V. anguillarum

Stock solutions of trypsin, pepsin, chymotrypsin (Sigma), and elastase from Pseudomonas aeruginosa (Elastin Products Company, Inc.) were serially diluted (1:2) in CSMHB to give final testing concentrations of protease in the wells ranging from 62.5 to $0.1 \mathrm{U} \mathrm{mL}^{-1}$ for trypsin and pepsin, 40 to $1.25 \mathrm{U} \mathrm{mL}^{-1}$ for chymotrypsin, and 2 to $0.01 \mathrm{U} \mathrm{mL}^{-1}$ for elastase. In addition to these commercially available proteases, extracellular proteins (ECP) of $P$. marinus were tested to see if proteases from this parasite could potentially inhibit AMP activity. The ECP, prepared from spent media of Perkinsus P-1 cultures, was kindly provided by C. Earnhart (Virginia Institute of Marine Sciences, VA, USA) (Earnhart et al. 2004). We also tested the effect of proteases present in the cell-free hemolymph (plasma) of eastern oysters, Crassostrea virginica, on antimicrobial activity. Oyster hemolymph from Block Island oysters (RI, USA) was obtained by cardiac puncture, centrifuged at $\times 1,500 \mathrm{~g}$ for $15 \mathrm{~min}$ at $4^{\circ} \mathrm{C}$ to remove the cells, and the plasma was concentrated using Microcon YM-50 centrifugal filter devices (Millipore), with the $\geq 50 \mathrm{kD}$ retentate fraction used for testing. Protein concentration in oyster plasma or P. marinus ECP was determined, using the Bradford protein assay (BioRad) and bovine plasma albumin as a standard (0-1.0 mg $\mathrm{mL}^{-1}$ ). Total protease activity in oyster plasma and $P$. marinus ECP was measured by incubation with azocasein (Windle \& Kelleher 1997). Azocasein (ICN Biomedicals) was dissolved in Tris- $\mathrm{HCl}(50 \mathrm{mM}, \mathrm{pH} 8.0)$ containing $0.04 \%(\mathrm{w} / \mathrm{v})$ sodium azide to a final concentration of $5 \mathrm{mg} \mathrm{mL}^{-1}$. One hundred $\mu \mathrm{L}$ of serial dilutions of ECP or oyster plasma sample were incubated with $100 \mu \mathrm{L}$ of azocasein for $1 \mathrm{~h}$ at $37^{\circ} \mathrm{C}$. The reaction was terminated by the addition of $400 \mu \mathrm{L}$ of $10 \%$ (w/v) trichloroacetic acid (Fisher Scientific). Precipitated protein was removed by centrifugation $(\times 14,000 \mathrm{~g}$ for $4 \mathrm{~min})$, and the resulting supernatant transferred to a tube containing $700 \mu \mathrm{L}$ of $525 \mathrm{mM}$ sodium hydroxide (Fisher Scientific). Absorbance was measured at $450 \mathrm{~nm}$ using a microplate reader (Molecular Devices). Negative controls consisted of heat inactivated plasma samples $\left(10 \mathrm{~min}\right.$ at $\left.100^{\circ} \mathrm{C}\right)$. Results are expressed as units (U) of protease activity with $1 \mathrm{U}$ of activity corresponding to a change from control of 1.0 optical unit of absorbance at $450 \mathrm{~nm}$. The $P$. marinus ECP fraction had a protein concentration of 0.5 $\mathrm{mg} \mathrm{mL} \mathrm{m}^{-1}$, with a protease activity of $10 \mathrm{U} \mathrm{mg}^{-1}$ of protein. Perkinsus marinus ECP was diluted in media (1:5 dilutions) to final testing concentrations, after additions of AMP solution ranging from $0.0008-0.25 \mathrm{U} \mathrm{mL}^{-1}$ protease activity. Concentrated oyster protease contained $760 \mu \mathrm{g} \mathrm{mL} \mathrm{m}^{-1}$ protein and $2.6 \mathrm{U} \mathrm{mL}^{-1}$ protease activity, final testing concentrations ranged from $0.08-0.5 \mathrm{U} \mathrm{mL}^{-1}$. One hundred $\mu \mathrm{L}$ of $2 \times \mathrm{MIC}$ for pleurocidin-amide $\left(5 \mu \mathrm{g} \mathrm{mL}^{-1}\right)$ or tachyplesin $\left(2.5 \mu \mathrm{g} \mathrm{mL}^{-1}\right)$ were added to each well, and plates were incubated for $24 \mathrm{~h}$ at $28^{\circ} \mathrm{C}$. Protease inhibitor cocktail for general use (Sigma), or $50 \mathrm{mM}$ EDTA for inhibition of oyster metalloproteinases (Muñoz et al. 2003), were added to selected wells as negative controls.

\section{Feeding Experiments}

Eastern oysters from Main Street Fish Shop (Wakefield, RI) were placed in $20 \mathrm{~L}$ tanks supplied with running, $2 \mu \mathrm{m}$-filtered and UV-sterilized seawater, and slowly brought up to $20^{\circ} \mathrm{C}$ over a 2-wk period. Water salinity and temperature ranged from $25 \%$ to $30 \%$ and $20^{\circ} \mathrm{C}$ to $25^{\circ} \mathrm{C}$, and oysters were fed with Instant Algae (Reed Mariculture). We evaluated oyster feeding rates on Tetraselmis sp. (Reed Mariculture), C. reinhardtii, $C$. pulsatilla, and $P$. pastoris, using the method of Rice et al. (1994). Individual oysters were placed in $2-\mathrm{L}$ containers with $1 \mathrm{~L}$ of aerated filtered seawater. A fixed concentration of algae (approximately 60,000 cells $\mathrm{mL}^{-1}$, Rice et al. 1994), or yeast (equivalent turbidity at $\mathrm{OD}_{650}$ ) was added to each container, mixed well, and $3 \times 1 \mathrm{~mL}$ samples were collected to estimate the starting cell concentration using a hemocytometer. Triplicate, $1-\mathrm{mL}$ samples were taken every 20 min over a period of $2 \mathrm{~h}$, 
and cell numbers counted. Throughout the entire experiment, oysters were checked visually to confirm that feeding was occurring by observing shells opening and the production of feces and pseudofeces. Rates of cell clearance were calculated using the equation:

$$
F=V[\ln (\mathrm{Co} / \mathrm{Ct}) / t],
$$

where $F$ is the filtration rate in $\mathrm{mL} \mathrm{min}^{-1}, V$ is the volume of the experimental container in $\mathrm{mL}, \ln (\mathrm{Co} / \mathrm{Ct})$ is the natural log of the cell concentration at time zero divided by the concentration at time $t$, and $t$ is the time in minutes (Coughlan 1969). Data were statistically analyzed with Sigma-Stat (SPSS), using KruskalWallis ANOVA on ranks, and Dunn pairwise comparisons, to compare rates of cell clearance.

\section{Effect of Antimicrobial Peptide Activity on Bacteria in Oyster Digestive Tissue}

Six oysters were obtained from Narragansett Bay (RI, USA) during the summer months. Samples of digestive tissues from each oyster were removed using aseptic techniques, pooled, homogenized, and diluted 1:5 in SASW. Serial dilutions of homogenate (no dilution, 1:10, and 1:100) were mixed with either tachyplesin, pleurocidin-amide (final peptide concentration of $20 \mu \mathrm{g} \mathrm{mL}^{-1}$ ), or SASW (negative control) and incubated at $19^{\circ} \mathrm{C}$ for $3 \mathrm{~h}$. Treated homogenate samples $(20 \mu \mathrm{L})$ were plated on peptone seawater agar, sheep's blood agar, and Thiosulfate Citrate Bile Sucrose Agar (TCBS, Difco) plates and incubated for $96 \mathrm{~h}$ at $19^{\circ} \mathrm{C}$. The number of bacterial colonies in each plate was counted and colonies were observed for colony and bacterial morphology (color, shape of colony, shape of bacterial cells, swarming behavior, and areas of hemolysis of sheep red blood cells or yellow halos on TCBS). A representative sample from each colony type was picked and suspended in Lyse-n-go (Pierce Scientific) for identification using sequencing of the $16 \mathrm{~S}$ rDNA (Gauger et al. 2006). A fragment of the $16 \mathrm{~S}$ rRNA of each bacterial clone was amplified using universal 16S primers pA and $\mathrm{pH}$ (Bruce et al. 1992) on a MJ Research PTC-100 thermocycler using the PCR Master Mix (Eppendorf). PCR products were run on a $1.5 \%$ Tris Acetate EDTA (TAE) agarose gel at $100 \mathrm{~V}$ for $30 \mathrm{~min}$. Bands visible at $\sim 1,500$ bp were cut and gel-purified, using the QIAquick gel extraction kit (Qiagen). Purified DNA from 33 products was sequenced on a Beckman Coulter CEQ 8000 sequencer at URI's Genomics Center. Sequences were identified by similarity with sequences in the NCBI and the $16 \mathrm{~S}$ ribosomal DNA genetic databases (RDP II, Ribosomal Database Project) (Cole et al. 2007) using a basic local alignment search tool (BLAST) (Altschul et al. 1990).

\section{RESULTS}

\section{Antimicrobial Assays}

The antimicrobial activities of tachyplesin and pleurocidinamide on a variety of marine pathogens and candidate eukaryotic organisms for recombinant expression are shown in Table 1. Tachyplesin proved to be more effective than pleurocidinamide against gram-negative bacteria and the gram-positive Bacillus spp. Pleurocidin had no effect on either $V$. vulnificus or $V$. parahemolyticus at the concentrations tested. These two bacterial strains showed higher resistance to the action of the
TABLE 1.

Activity spectrum of tachyplesin and pleurocidin-amide against selected bacteria and potential eukaryotic organisms for recombinant expression using the $\mathbf{9 6}$ well microdilution assay. Results are reported as the range of minimum inhibitory concentrations (MIC) from at least 2 assays. Each concentration was tested in triplicate. NT $=$ not tested.

\begin{tabular}{lcc}
\hline \hline & \multicolumn{2}{c}{ MIC $\left(\boldsymbol{\mu g} \mathbf{~ m L}^{\mathbf{- 1}}\right)$} \\
\cline { 2 - 3 } & Pleurocidin-amide & Tachyplesin \\
\hline Gram-positive bacteria & $2.5-5.0$ & 1.25 \\
Bacillus spp. & & \\
Gram-negative bacteria & 5.0 & $1.25-2.5$ \\
Escherichia coli $Z K 4$ & $1.25-2.5$ & 1.25 \\
E. coli D31 & $0.63-2.5$ & $0.625-1.25$ \\
Vibrio anguillarum & 2.5 & $0.625-1.25$ \\
V. harveyi & $>5.0$ & 2.5 \\
V. vulnificus & $>5.0$ & $1.25-5.0$ \\
V. parahemolyticus & 1.25 & 0.45 \\
Pseudomonas atlantica & 2.5 & 2.5 \\
P. damselae damselae & & \\
Yeast & $>20$ & $>20$ \\
Saccharomyces cerevisiae & $>20$ & $>20$ \\
Pichia pastoris & & NT \\
Microalgae & $>5.0$ & $0.63-1.25$ \\
Chlamydomonas pulsatilla & 1.25 & $>50$ \\
C. reinhardtii & $\mathrm{NT}$ & \\
Skeletonema costatum & &
\end{tabular}

AMPs than any of the bacteria tested. Both potential yeast for AMP recombinant expression were resistant to the candidate antimicrobial peptides at the highest concentration tested $(20 \mu \mathrm{g}$ $\mathrm{mL}^{-1}$ ). The microalgae $C$. reinhardtii showed higher susceptibility to these two AMPs, comparable to the most susceptible bacteria tested in this study. Pleurocidin-amide had no effect on C. pulsatilla and tachyplesin had no effect on S. costatum at the concentrations tested. Neither salinity nor $\mathrm{pH}$ had an effect on the MIC of tachyplesin; a slight decrease in pleurocidin's MIC was observed at a salinity of $30 \%$ (Table 2 ).

TABLE 2.

Activity of antimicrobial peptides against Vibrio anguillarum at various $\mathrm{pH}$ and $\mathrm{NaCl}$ concentrations. Results are reported as the range of minimum inhibitory concentration (MIC) from at least 2 assays. Each concentration or $\mathrm{pH}$ was tested in triplicate.

\begin{tabular}{lll}
\hline \hline & \multicolumn{2}{c}{ MIC $\boldsymbol{\mu g ~ \mathbf { ~ m L } ^ { - \mathbf { 1 } }}$} \\
\cline { 2 - 3 } & Pleurocidin-amide & Tachyplesin \\
\hline Salinity $(\% \mathrm{NaCl})$ & & \\
15 & 2.5 & 1.25 \\
20 & 2.5 & 1.25 \\
25 & 2.5 & 1.25 \\
30 & 2.5 & 2.5 \\
$\mathrm{pH}$ & & \\
6.0 & 5 & $1.25-2.5$ \\
7.0 & $2.5-5$ & $1.25-2.5$ \\
8.0 & 5 & 2.5 \\
\hline
\end{tabular}


Effect of Antimicrobial Peptides on Perkinsus marinus Viability

Both peptides significantly reduced $P$. marinus viability at concentrations higher than $50 \mu \mathrm{g} \mathrm{mL}^{-1}$ (Fig. 1). Tachyplesin showed a greater effect than pleurocidin-amide on the viability of $P$. marinus. The viability of $P$. marinus was reduced to $9 \%$ with $50 \mu \mathrm{g} \mathrm{mL}^{-1}$ of tachyplesin, and to approximately $50 \%$ with $50 \mu \mathrm{g} \mathrm{mL}^{-1}$ of pleurocidin-amide. The viability of $P$. marinus was reduced to only $22 \%$ with concentrations of pleurocidin as high as $250 \mu \mathrm{g} \mathrm{mL} L^{-1}$.

\section{Effect of Proteases on Antimicrobial Activity}

The aspartic protease pepsin (up to $62.5 \mathrm{U} \mathrm{mL}^{-1}$ ) had no effect on the antimicrobial activity of either tachyplesin or pleurocidin against $V$. anguillarum (Table 3). The serine proteases trypsin and chymotrypsin abrogated the inhibitory activity of tachyplesin and pleurocidin-amide at concentrations as low as 1 and $0.5 \mathrm{U} \mathrm{mL}^{-1}$ respectively. Concentrated oyster plasma and $P$. marinus extracellular protein (both containing protease activity), and $P$. aeruginosa elastase, all had no effect on the activity of tachyplesin at the concentrations tested. Pleurocidin-amide was sensitive to both elastase and oyster plasma, and very sensitive to the effects of $P$. marinus ECP. The addition of protease inhibitors negated the effects of all proteases on the antimicrobial activity of the peptides (not shown) with identical MIC ranges.

\section{Feeding Experiments}

Clearance rate experiments were conducted to show that oysters could feed on several candidate organisms that could be used as systems to produce recombinant AMPs. The mean clearance rate of microalgal and yeast strains by experimental oysters ranged from $12.3-33.6 \mathrm{~mL} \mathrm{~min}^{-1}$ (Table 4). No significant differences in clearance rate were observed for Tetraselmis sp. (average of $12 \mu \mathrm{m}$ in size), C. reinhardtii $(10 \mu \mathrm{m})$, or $C$. pulsatilla $(10 \mu \mathrm{m})$. Clearance rates $\left(\mathrm{mL} \mathrm{min}^{-1}\right)$ were significantly lower for the yeast $P$. pastoris than for the algae Tetraselmis sp. and $C$. pulsatilla. The clearance rate, as expressed in cells $\min ^{-1}$ was significantly higher for $P$. pastoris, the organism with the smallest cells (average of $5 \mu \mathrm{m}$ in size).

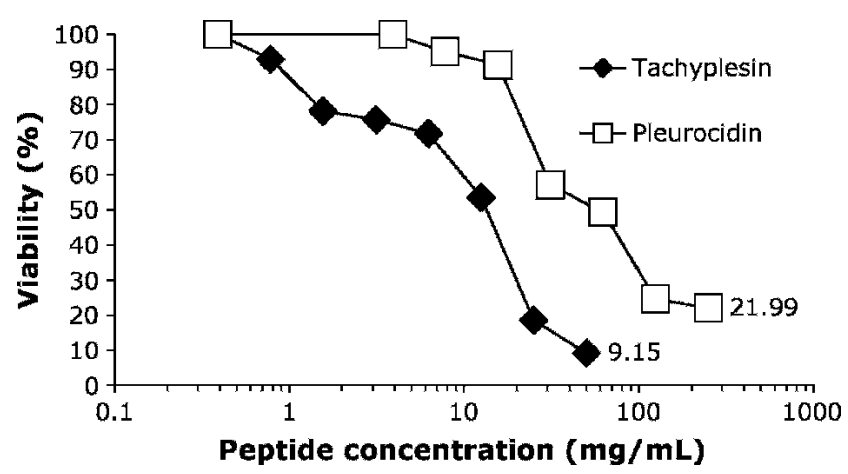

Figure 1. Effect of tachyplesin and pleurocidin-amide on the viability of Perkinsus marinus. Final concentrations of the peptides ranged from 0.36 to $50 \mu \mathrm{g} \mathrm{mL}^{-1}$ for tachyplesin and from 3.12 to $200 \mu \mathrm{g} \mathrm{mL}^{-1}$ for pleurocidin-amide. Peptides were coincubated with $2 \times 10^{6}$ cells $\mathrm{mL}^{-1}$ $P$. marinus and viability at $48 \mathrm{~h}$ was measured and calculated using a commercial tetrazolium assay.
TABLE 3.

Amount of protease required to inhibit the antimicrobial activity of pleurocidin-amide $\left(2.5 \mu \mathrm{g} \mathrm{mL}{ }^{-1}\right)$ or tachyplesin $\left(1.25 \mu \mathrm{g} \mathrm{mL}^{-1}\right)$ against Vibrio anguillarum. Proteases and peptides were coincubated for $30 \mathrm{~min}$ and antimicrobial activity was evaluated at $24 \mathrm{~h}$. Results are reported as the range of protease concentration from at least 2 assays. Each concentration was tested in triplicate.

\begin{tabular}{lcc}
\hline \hline & \multicolumn{2}{c}{ Protease Concentration $\left(\mathbf{U} \mathbf{~ m L}^{\mathbf{- 1}}\right)$} \\
\cline { 2 - 3 } & Pleurocidin-amide & Tachyplesin \\
\hline Pepsin & 62.5 & 62.5 \\
Trypsin & $0.5-1.0$ & $1.0-2.0$ \\
Chymotrypsin & $0.3-0.6$ & 1.3 \\
Elastase & 0.12 & $>2.00$ \\
Oyster plasma & 0.07 & $>0.50$ \\
Perkinsus marinus ECP & 0.0008 & $>0.25$ \\
\hline
\end{tabular}

ECP, extracellular proteins.

Effect of Antimicrobial Peptide Activity on Bacteria in Oyster Tissue Homogenate

An average of $43 \pm 6$ bacterial colonies (CFU) were observed on the 6 plates seeded with oyster tissue homogenate treated with SASW. Incubation of the oyster homogenate $(1.23 \mathrm{mg}$ $\mathrm{mL}^{-1}$ of protein) with pleurocidin-amide and tachyplesin significantly reduced the number of CFU in oyster tissue, with an average of $4 \pm 1$ and $7 \pm 2$ colonies detected in either the pleurocidin-amide or the tachyplesin-treated homogenates (a reduction in bacterial abundance after treatment with AMP ranging from $82 \%$ to $94 \%$ ). All but 2 of the representative bacterial colonies present on plates incubated with the AMPs were putatively identified based on their $16 \mathrm{~S}$ rDNA sequences, as well as 15 of the 17 representative colonies from the 43 colonies that grew on control plates (Table 5, GenBank accession numbers DQ978244 to DQ978271). Control oyster homogenates plates showed a mix of gram-negative and grampositive bacteria. The bacteria that grew in the presence of pleurocidin-amide were all identified as gram-negative bacteria, the majority of which were vibrios. Conversely, those that grew

\section{TABLE 4.}

Clearance by oysters of algae and candidate eukaryotic organisms for recombinant expression of AMPs. Oysters in individual glass beakers were fed a fixed concentration of yeast or algae and the concentration of cells measured in the water at fixed time points. $n=$ number of oysters used in experiment.

\begin{tabular}{|c|c|c|}
\hline & \multicolumn{2}{|c|}{$\begin{array}{c}\text { Mean Clearance Rate } \\
\text { Deviation }\end{array}$} \\
\hline & $\left(\mathrm{mL} \min ^{-1}\right)$ & $\left(\right.$ million cells min $\left.^{-1}\right)$ \\
\hline Tetraselmis sp. $(n=6)$ & $33.6 \pm 12.1^{\mathrm{a}}$ & $2.08 \pm 0.71$ \\
\hline $\begin{array}{l}\text { Chlamydomonas reinhardtii } \\
\quad(n=12)\end{array}$ & $29.1 \pm 26.4$ & $1.87 \pm 1.18^{\mathrm{d}}$ \\
\hline C. pulsatilla $(n=12)$ & $31.6 \pm 19.8^{b}$ & $0.89 \pm 0.32^{\mathrm{c}}$ \\
\hline Pichia pastoris $(n=12)$ & $12.3 \pm 5.2^{\mathrm{a}, \mathrm{b}}$ & $10.04 \pm 2.86^{\mathrm{c}, \mathrm{d}}$ \\
\hline
\end{tabular}

a,b,c,d Same letter indicates statistical significance $(P<0.05)$ using Kruskal-Wallis ANOVA on ranks, and Dunn's pairwise comparisons. AMPs, antimicrobial peptides. 


\section{TABLE 5.}

Effect of AMPs on abundance and composition of the culturable bacterial community in homogenates of oyster digestive tissue. Values are total number of colonies per oyster tissue sample (24.6 $\mu \mathrm{g}$ of protein). Bacterial isolates were identified by $16 \mathrm{~S}$ rDNA sequencing. All sequence similarities from ribosomal database (RDPII) $>98 \%$. Genbank sequence accession numbers DQ978244 to DQ978271.

\begin{tabular}{|c|c|c|c|}
\hline & Control & Pleurocidin & Tachyplesin \\
\hline \multicolumn{4}{|l|}{ Gram-positive bacteria } \\
\hline Bacillus pumilus & 3 & - & 1 \\
\hline Bacillus sp. & - & - & 1 \\
\hline Staphylococcus epidermis & 5 & - & - \\
\hline S. hemolyticus/hominus & 1 & - & 3 \\
\hline Gram-negative bacteria & - & - & - \\
\hline Enhydrobacter sp. & - & - & 1 \\
\hline Microbacterium sp. & 1 & - & - \\
\hline Photobacterium damselae & & & \\
\hline damselae & - & 3 & 1 \\
\hline Pseudoalteromonas sp. & 1 & - & - \\
\hline Vibrio sp. TD29, TD35 & 2 & - & - \\
\hline Vibrio sp. TD25 & 1 & - & - \\
\hline Vibrio sp. TD15 & - & 1 & - \\
\hline Vibrio sp. TD16, TD20 & - & 2 & - \\
\hline Vibrio sp. TD9 & - & 1 & - \\
\hline Not identified & 3 & 1 & 1 \\
\hline
\end{tabular}

AMPs, antimicrobial peptides.

after coincubation of oyster tissue with tachyplesin were mainly gram-positive. Five of the representative isolates could not be identified because of lack of amplification, or the inability to obtain sequences of adequate quality.

\section{DISCUSSION}

Candidate peptides for feed-based delivery to aquaculture species should be effective in the challenging environment of marine culture, and the digestive system of the target host. We show here that tachyplesin is more suitable than pleurocidinamide as a candidate for use in a feed-based delivery system for shellfish aquaculture. Tachyplesin was more effective than pleurocidin-amide in inhibiting the growth of a variety of bacteria commonly found in marine environments, and performed well at the range of $\mathrm{pH}$ and salinities expected in marine culture conditions and the oyster tissues (Langdon \& Newell 1996). Tachyplesin was also more resistant to the effects of proteases from the parasite $P$. marinus and some of those more commonly found in the digestive systems of finfish and shellfish (Garcia-Carreno et al. 2003, Srivastava et al. 2002). Finally, several of the potential candidates for eukaryotic expression systems we have tested, such as $P$. pastoris, are more resistant to the action of tachyplesin than bacteria, and could in theory produce enough AMPs to be effective in the treatment of common bacterial infections (Ingham \& Moore 2007).

In general, the levels of antimicrobial activity of tachyplesin and pleurocidin-amide against a variety of bacterial strains and species were similar to those previously reported in the literature (Iwanaga et al. 1994a, Jia et al. 2000, Miyata et al. 1989, Morvan et al. 1997). Interestingly, the activity of pleurocidinamide against $V$. parahemolyticus and $V$. vulnificus was found to be greater than the maximum concentration tested $\left(5 \mu \mathrm{g} \mathrm{mL}^{-1}\right)$. The MIC for native pleurocidin against $V$. parahemolyticus has been shown to be as high as $187 \mu \mathrm{g} \mathrm{mL}$, indicating resistance of these bacteria to the action of some antimicrobial peptides (Burrowes et al. 2004). These observations indicate that pleurocidin would not be effective in oyster depuration.

Our results showed that tachyplesin and pleurocidin-amide were effective in reducing the viability of Perkinsus marinus, a pathogen commonly found in adult eastern oysters in the Atlantic and Gulf of Mexico coasts of the United States during the warm months (Villalba et al. 2004), but only at AMP concentrations that inhibited the growth of some of the potential eukaryotic systems considered for the feed-based delivery of recombinant antimicrobials to oysters. Tachyplesin, which has been shown to have antimycotic properties (Iwanaga et al. 1994b), was more effective than pleurocidin-amide. This is consistent with the fact that $P$. marinus is extremely sensitive to antimycotics, whereas highly resistant to antibacterials (Dungan \& Hamilton 1995). The only published evidence of tachyplesin having an effect against $P$. marinus showed a comparable reduction of viability at concentrations higher than the ones shown in our research $(38 \%$ viability when treated with $500 \mu \mathrm{g} \mathrm{mL}^{-1}$ [Morvan et al. 1997] versus $9 \%$ viability at $50 \mu \mathrm{g}$ $\mathrm{mL}^{-1}$ in our study). Differences in these results may be because of the sensitivity of the method used to determine parasite viability. Whereas Morvan et al. (1997) used microscopic examination and a dye-exclusion assay to determine cell viability, we used a tetrazolium-based enzymatic assay that measures metabolic activity, after allowing surviving $P$. marinus cells to propagate for $48 \mathrm{~h}$ postexposure. This method is, in general, more reliable than turbidity assays and counting methods because $P$. marinus cells have heterogeneous sizes and aggregate easily. Polyphemusin, an antimicrobial peptide from the horseshoe crab Limulus polyphemus with strong similarity to tachyplesin, was shown to have an MIC of only $12 \mu \mathrm{g} \mathrm{mL}^{-1}$ for P. marinus (Pierce et al. 1997).

Proteases are considered a significant impediment to the use of antimicrobial peptides in vivo (Andreu \& Rivas 1998). Although proteases are needed for AMP activation by cleaving the inactive precursor signal peptide, they also cause degradation of the mature active form (Shinnar et al. 2003). The high content in basic residues of AMPs favors degradation by the trypsin-like proteases (Andreu \& Rivas 1998), as observed in our experiments. It is important to characterize the effect of relevant proteases on peptide activity prior to application, particularly because the virulence of many pathogenic strains is related to the level of the proteases that they produce. Perkinsus marinus secretes proteases that degrade host proteins and may damage the gut epithelium and basement membranes of oysters (Garreis et al. 1996, La Peyre et al. 1996). Therefore, any candidate peptide for treatment and depuration of adult eastern oysters should be tested for its ability to maintain antimicrobial activity in the presence of this protozoan parasite. We were able to show that tachyplesin retained its potency in the presence of concentrated $P$. marinus extracellular products (ECP), but pleurocidin was inactivated at relatively low levels of protease activity. The sensitivity of pleurocidin-amide to the action of $P$. marinus ECP may be because of the structure of this peptide, which contains two groups of consecutive alanines at $\mathrm{Ala}^{9}-\mathrm{Ala}^{10}$ and $\mathrm{Ala}^{19}-\mathrm{Ala}^{20}$. It has been shown that $P$. marinus 
Antimicrobial Peptides for Oyster Aquaculture

serine protease was effective in digesting a $C$. virginica $35 \mathrm{kDa}$ plasma protein, which consisted of many alanine residues (Oliver et al. 1999). The serine protease elastase is also more efficient at hydrolyzing peptide substrates with consecutive alanine residues (Kraut 1977). Consistent with this fact, elastase from $P$. aeruginosa degraded the microbicidal activity of pleurocidin-amide, but not tachyplesin. The relative resistance of tachyplesin to the action of proteases is more likely because of secondary structure where the formation of a hairpin loop (via disulfide bonds) protects the peptide sequence from proteolysis. Several other peptides show modifications that decrease the effect of proteases. For example, mammalian cathelicidins are resistant to serine proteases by virtue of the presence of proline, a cyclic residue that blocks protease action, in their sequences. The same peptides from hagfish have bromination of tryptophan, which makes them poor substrates for degradation (Shinnar et al. 2003).

We have also shown that tachyplesin and pleurocidin-amide are able to effectively reduce bacterial loads in homogenates of oyster digestive tissue. Differences in the composition of the bacterial community remaining after treatment with either pleurocidin (primarily gram-negatives) or tachyplesin (primarily gram-positives) suggest differences in the mechanism of action of these peptides, which seem to selectively act on different bacterial communities, although it is difficult to confidently conclude this, based on the low number of colonies. These differences in the in vivo selectivity of tachyplesin and pleurocidin-amide could be exploited to target particular pathogens without affecting some of the beneficial bacterial species indigenous to the oyster gut. For example, the fact that tachyplesin selectively eliminates more gram-negative than gram-positive bacteria could be advantageous in aquaculture applications, because many of the probiotics that are used are gram-positive and many pathogens are gram-negative (Chinabut \& Puttinaowarat 2005).

We have also evaluated the suitability of several candidate eukaryotic organisms that could be used in the expression and feed-based delivery of recombinant AMPs. The advantages of yeast as a system for recombinant expression include the availability of plasmid DNA vectors and tools for inducible and constitutive expression, the ability of yeast to correctly fold and process proteins (Romanos et al. 1992), and its use as a food source in aquaculture (Lara-Flores et al. 2003, Patra \& Mohamed 2003). In our experiments, the yeast $P$. pastoris and $S$. cerevisiae were not affected by tachyplesin or pleurocidinamide at concentrations lower than $20 \mu \mathrm{g} \mathrm{mL}^{-1}$, a concentration that significantly (but not completely) reduced bacterial loads in homogeneates of oyster digestive tissue. However, it has previously been reported that tachyplesin's $\mathrm{IC}_{50}$ against $P$. pastoris is $0.1 \mu \mathrm{g} \mathrm{mL}^{-1}$ (Iwanaga 2002), and pleurocidin's MIC is $9 \mu \mathrm{g}$ $\mathrm{mL}^{-1}$ (Burrowes et al. 2004). These levels of susceptibility to antimicrobial action would preclude the use of yeasts and Chlamydomonas spp. as systems for expression of active antimicrobial peptides, as well as the use of a feed-based delivery system for treatment of parasitic infections. Furthermore, significant differences in mean clearance rates were observed between Tetraselmis sp., a common algae used in oyster aquaculture, and $P$. pastoris, which may be indicative of differences in the feeding behavior of oysters that could impact the success of $P$. pastoris as a delivery system. Oysters seem to actively distinguish and sort nutritious from nonnutritious particles (Ward \& Shumway 2004). In our experiments adult oysters were able to filter $P$. pastoris from the water; however, we do not know if contents of those cells were actively digested and assimilated.

In summary, the antimicrobial peptide tachyplesin was shown to be a more suitable candidate than pleurocidin-amide for feed-based delivery to oysters. A feed-based delivery system of antimicrobial peptides would be a valuable tool in investigating the role of peptides on oyster immunity. Our data also suggests that a feed-based delivery of recombinant tachyplesin could be developed to effectively and economically treat bacterial infections in oyster hatcheries. Although yeasts seem to be the best candidates so far as systems for a feed-based delivery system of antimicrobials to oysters, more research needs to be conducted to determine levels of resistance to antimicrobial action and suitability as feeds for larval, seed, and adult oysters. Further experiments should also evaluate alternative expression systems, such as diatoms (Dunahay et al. 1997). Furthermore, the development of such systems for commercial applications in hatcheries should take into consideration, and minimize, the risk of these genetically modified organisms to the bivalve host, the human consumer, and the environment.

\section{ACKNOWLEDGMENTS}

The authors thank Chris Earnhart for providing P. marinus ECPs, Ken LaValley and Eric Gauger for providing bacterial cultures, and Dina Proestou and David C. Smith (URI) for helpful comments. This research was supported by USDA NRICGP 2000-01264.

\section{LITERATURE CITED}

Altschul, S. F., W. Gish, W. Miller, E. W. Myers \& D. J. Lipman. 1990. Basic local alignment search tool. J. Mol. Biol. 215:403-410.

Anderson, R. S. \& A. E. Beaven. 2001. Antibacterial activities of oyster (Crassostrea virginica) and mussel (Mytilus edulis and Geukensia demissa) plasma. Aquat. Living Res. 14:343-349.

Andreu, D. \& L. Rivas. 1998. Animal antimicrobial peptides: an overview. Biopolymers 47:415-433.

Berthe, F. C. J., F. Le Roux, R. D. Adlard \& A. Figueras. 2004. Marteiliosis in molluscs: A review. Aquat. Living Res. 17:433448.

Bruce, K. D., W. D. Hiorns, J. L. Hobman, A. M. Osborn, P. Strike \& D. A. Ritchie. 1992. Amplification of DNA from native populations of soil bacteria by using the polymerase chain reaction. Appl. Environ. Microbiol. 58:3413-3416.

Buchanan, J. T., T. C. Cheng, J. F. La Peyre, R. K. Cooper \& T. R. Tiersch. 2001. In vivo transfection of adult eastern oysters Crassostrea virginica. J. World Aquac. Soc. 32:286-299.

Burreson, E. M. \& S. E. Ford. 2004. A review of recent information on the Haplosporidia, with special reference to Haplosporidium nelsoni (MSX disease). Aquat. Living Resour. 17:499-517.

Burrowes, O. J., C. Hadjicharalambous, G. Diamond \& T. C. Lee. 2004. Evaluation of antimicrobial spectrum and cytotoxic activity of pleurocidin for food applications. J. Food Sci. 69:M66-M71. 
Carnegie, R. B. \& N. Cochennec-Laureau. 2004. Microcell parasites of oysters: Recent insights and future trends. Aquat. Living Resour. 17:519-528.

Chinabut, S. \& S. Puttinaowarat. 2005. The choice of disease control strategies to secure international market access for aquaculture products. Dev. Biol. (Basel) 121:255-261.

Cole, A. M., R. O. Darouiche, D. Legarda, N. Connell \& G. Diamond. 2000. Characterization of a fish antimicrobial peptide: gene expression, subcellular localization, and spectrum of activity. Antimic. Agents Chemother. 44:2039-2045.

Cole, A. M., P. Weis \& G. Diamond. 1997. Isolation and characterization of pleurocidin, an antimicrobial peptide in the skin secretions of winter flounder. J. Biol. Chem. 272:12008-12013.

Cole, J. R., B. Chai, R. J. Farris, Q. Wang, A. S. Kulam-SyedMohideen, D. M. McGarrell, A. M. Bandela, E. Cardenas, G. M Garrity \& J. M. Tiedje. 2007. The ribosomal database project (RDPII): introducing myRDP space and quality controlled public data. Nucleic Acids Res. 35:D169-D172.

Coughlan, J. 1969. The estimation of filtration rates from the clearance of suspended particles. Mar. Biol. 2:356-358.

Dalsgaard, I. 2001. Selection of media for antimicrobial susceptibility testing of fish pathogenic bacteria. Aquaculture 196:267-275.

Denkin, S. M. \& D. R. Nelson. 1999. Induction of protease activity in Vibrio anguillarum by gastrointestinal mucus. Appl. Environ. Microbiol. 65:3555-3560.

Douglas, S. E., A. Patrzykat, J. Pytyck \& J. W. Gallant. 2003. Identification, structure and differential expression of novel pleurocidins clustered on the genome of the winter flounder, Pseudopleuronectes americanus (Walbaum). Eur. J. Biochem. 270:3720-3730.

Dunahay, T. G., S. A. Adler \& J. W. Jarvik. 1997. Transformation of microalgae using silicon carbide whiskers. Methods Mol. Biol. 62:503-509.

Dungan, C. F. \& R. M. Hamilton. 1995. Use of a tetrazolium-based cell proliferation assay to measure effects of in vitro conditions on Perkinsus marinus (Apicomplexa) proliferation. J. Euk. Microbiol. 42:379-388.

Earnhart, C. G., M. A. Vogelbein, G. D. Brown, K. S. Reece \& S. L. Kaattari. 2004. Supplementation of Perkinsus marinus cultures with host plasma or tissue homogenate enhances their infectivity. Appl. Environ. Microbiol. 70:421-431.

Fjell, C. D., R. E. Hancock \& A. Cherkasov. 2007. AMPer: a database and an automated discovery tool for antimicrobial peptides. Bioinformatics 23:1148-1155.

Garcia-Carreno, F. L., M. A. Navarrete del Toro \& E. ServiereZaragoza. 2003. Digestive enzymes in juvenile green abalone, Haliotis fulgens, fed natural food. Comp. Biochem. Physiol. B Biochem. Mol. Biol. 134:143-150.

Garreis, K. A., J. F. La Peyre \& M. Faisal. 1996. The effects of Perkinsus marinus extracellular products and purified proteases on oyster defence parameters in vitro. Fish Shellfish Immunol. 6:581-597.

Gauger, E., R. Smolowitz, K. Uhlinger, J. Casey \& M. Gomez-Chiarri 2006. Vibrio harveyi and other bacterial pathogens in cultured summer flounder, Paralichthys dentatus. Aquaculture 260:10-20.

Gonzalez, M., Y. Gueguen, G. Desserre, J. de Lorgeril, B. Romestand \& E. Bachere. 2007. Molecular characterization of two isoforms of defensin from hemocytes of the oyster Crassostrea gigas. Dev. Comp. Immunol. 31:332-339.

Gorman, D. S. \& R. P. Levine. 1965. Cytochrome f and plastocyanin: their sequence in the photosynthetic electron transport chain of Chlamydomonas reinhardtii. Proc. Natl. Acad. Sci. USA 54:1665-1669.

Gueguen, Y., A. Herpin, A. Aumelas, J. Garnier, J. Fievet, J. M. Escoubas, P. Bulet, M. Gonzalez, C. Lelong, P. Favrel \& E. Bachere. 2005. Characterization of a defensin from the oyster Crassostrea gigas: Recombinant production, folding, solution structure, antimicrobial activities and gene expression. J. Biol. Chem. 28:313-332.

Gulig, P. A., K. L. Bourdage \& A. M. Starks. 2005. Molecular pathogenesis of Vibrio vulnificus. J. Microbiol. 43 Spec No:118-131.
Ingham, A. B. \& R. J. Moore. 2007. Recombinant production of antimicrobial peptides in heterologous microbial systems. Biotechnol. Appl. Biochem. 47:1-9.

Iwanaga, S. 2002. The molecular basis of innate immunity in the horseshoe crab. Curr. Opin. Immunol. 14:87-95.

Iwanaga, S., T. Muta, T. Shigenaga, Y. Miura, N. Seki, T. Saito \& S. Kawabata. 1994a. Role of hemocyte-derived granular components in invertebrate defense. Ann. N. Y. Acad. Sci. 712:102-116.

Iwanaga, S., T. Muta, T. Shigenaga, N. Seki, K. Kawano, T. Katsu \& S. Kawabata. 1994b. Structure-function relationships of tachyplesins and their analogues. Ciba Found. Symp. 186:160-174.

Jia, X., A. Patrzykat, R. H. Devlin, P. A. Ackerman, G. K. Iwama \& R. E. W. Hancock. 2000. Antimicrobial peptides protect coho salmon from Vibrio anguillarum infections. Appl. Environ. Microbiol. 66:1928-1932.

Kraut, J. 1977. Serine proteases: structure and mechanism of catalysis. Annu. Rev. Biochem. 46:331-358.

La Peyre, J. F., H. A. Yarnall \& M. Faisal. 1996. Contribution of Perkinsus marinus Extracellular Products in the infection of Eastern Oysters (Crassostrea virginica). J. Invertebr. Pathol. 68:312313.

Langdon, C. J. \& R. I. E. Newell. 1996. Digestion and nutrition of larvae and adults. In: V. S. Kennedy, R. I. E. Newell \& A. Eble, editors. The eastern oyster, Crassostrea virginica. Maryland Sea Grant Publication. pp. 231-270.

Lara-Flores, M., M. A. Olvera-Novoa, B. E. Guzman-Mendez \& W. Lopez-Madrid. 2003. Use of the bacteria Streptococcus faecium and Lactobacillus acidophilus, and the yeast Saccharomyces cerevisiae as growth promoters in Nile tilapia (Oreochromis niloticus). Aquaculture 216:193-201.

Miyata, T., F. Tokunaga, T. Yoneya, K. Yoshikawa, S. Iwanaga, M. Niwa, T. Takao \& Y. Shimonishi. 1989. Antimicrobial peptides, isolated from horseshoe crab hemocytes, tachyplesin II, and polyphemusins I and II: Chemical structures and biological activity. J. Biochem. (Tokyo) 106:663-668.

Mookherjee, N. \& R. E. Hancock. 2007. Cationic host defence peptides: Innate immune regulatory peptides as a novel approach for treating infections. Cell. Mol. Life Sci. 64:922-933.

Morvan, A., E. Bachere, P. P. Da Silva, P. Pimenta \& E. Mialhe. 1994. In vitro activity of the antimicrobial peptide magainin 1 against Bonamia ostreae, the intrahemocytic parasite of the flat oyster Ostrea edulis. Mol. Mar. Biol. Biotechnol. 3:327-333.

Morvan, A., S. Iwanaga, M. Comps \& E. Bachere. 1997. In vitro activity of the Limulus antimicrobial peptide Tachyplesin I on marine bivalve pathogens. J. Invertebr. Pathol. 69:177-182.

Muñoz, P., K. Vance \& M. Gomez-Chiarri. 2003. Protease activity in the plasma of American oysters, Crassostrea virginica, experimentally infected with the protozoan parasite Perkinsus marinus. J. Parasitol. 89:941-951.

Murakami, T., M. Niwa, F. Tokunaga, T. Miyata \& S. Iwanaga. 1991. Direct virus inactivation of tachyplesin I and its isopeptides from horseshoe crab hemocytes. Chemotherapy 37:327-334.

Nakamura, T., H. Furunaka, T. Miyata, F. Tokunaga, T. Muta, S. Iwanaga, M. Niwa, T. Takao \& Y. Shimonishi. 1988. Tachyplesin, a class of antimicrobial peptide from the hemocytes of the horseshoe crab (Tachypleus tridentatus). Isolation and chemical structure. J. Biol. Chem. 263:16709-16713.

Oliver, J. L., T. D. Lewis, M. Faisal \& S. L. Kaattari. 1999. Analysis of the effects of Perkinsus marinus proteases on plasma proteins of the Eastern oyster (Crassostrea virginica) and the Pacific oyster (Crassostrea gigas). J. Invertebr. Pathol. 74:173-183.

Paillard, C., F. Le Roux \& J. J. Borreg. 2004. Bacterial disease in marine bivalves, a review of recent studies: Trends and evolution. Aquat. Living Resour. 17:477-498.

Patra, S. K. \& K. S. Mohamed. 2003. Enrichment of Artemia nauplii with the probiotic yeast Saccharomyces boulardii and its resistance against a pathogenic Vibrio. Aquaculture International 11:505-514. 
Pereira, H. A. 2006. Novel therapies based on cationic antimicrobial peptides. Curr. Pharm. Biotechnol. 7:229-234.

Pierce, J. C., W. L. Maloy, L. Salvador \& C. F. Dungan. 1997. Recombinant expression of the antimicrobial peptide polyphemusin and its activity against the protozoan oyster pathogen Perkinsus marinus. Mol. Mar. Biol. Biotechnol. 6:248-259.

Reece, K. S., D. Bushek, K. L. Hudson \& J. Graves. 2001. Geographic distribution of Perkinsus marinus genetic strains along the Atlantic and Gulf coasts of the USA. Mar. Biol. 139:1047-1055.

Rice, M. A., R. B. Rheault, M. S. Perez \& V. S. Perez. 1994. Experimental culture and particle filtration by Asian moon scallops, Amusium pleuronectes. Asian Fish. Sci. 7:179-185.

Romanos, M. A., C. A. Scorer \& J. J. Clare. 1992. Foreign gene expression in yeast: a review. Yeast 8:423-488.

Sarmasik, A., G. Warr \& T. T. Chen. 2002. Production of transgenic medaka with increased resistance to bacterial pathogens. Mar. Biotechnol. 4:310-322.

Seo, J. K., J. M. Crawford, K. L. Stone \& E. J. Noga. 2005. Purification of a novel arthropod defensin from the American oyster, Crassostrea virginica. Biochem. Biophys. Res. Commun. 338:1998-2004.

Shinnar, A. E., K. L. Butler \& H. J. Park. 2003. Cathelicidin family of antimicrobial peptides: Proteolytic processing and protease resistance. Bioorganic Chem. 31:425-436.
Srivastava, A. S., T. Kurokawa \& T. Suzuki. 2002. mRNA expression of pancreatic enzyme precursors and estimation of protein digestibility in first feeding larvae of the Japanese flounder, Paralichthys olivaceus. Comp. Biochem. Physiol. A Mol. Int. Physiol. 132:629635.

Tincu, J. A. \& S. W. Taylor. 2004. Antimicrobial peptides from marine invertebrates. Antimicrob. Agents Chemother. 48:3645-3654.

Vici, V., I. S. B. Singh \& S. G. Bhat. 2000. Application of bacterins and yeast Acremonium dyosporii to protect the larvae of Macrobrachium rosenbergii from vibriosis. Fish Shellfish Immunol. 10:559-563.

Villalba, A., K. S. Reece, M. C. Ordas, S. M. Casas \& A. Figueras. 2004. Perkinsosis in molluscs: A review. Aquat. Living Resour. 17:411-432.

Wang, Z. \& G. Wang. 2004. APD: the Antimicrobial Peptide Database. Nucleic Acids Res. 32:D590-D592.

Ward, J. E. \& S. E. Shumway. 2004. Separating the grain from the chaff: particle selection in suspension- and deposit-feeding bivalves. J. Exp. Mar. Biol. Ecol. 300:83-130.

Windle, H. J. \& D. Kelleher. 1997. Identification and characterization of a metalloprotease activity from Helicobacter pylori. Infect. Immun. 65:3132-3137.

Yeung, P. S. \& K. J. Boor. 2004. Epidemiology, pathogenesis, and prevention of foodborne Vibrio parahaemolyticus infections. Foodborne Pathog. Dis. 1:74-88. 